DOI: 10.34015/2523-4552.2020.4.07

Удк 340.15

Прус В. 3.,

кандидат юридичних наук, доцент

доцент кафедри історії держави

та права Національної академії

внутрішніх справ

e-mai:pvz_@ukr.net

ORCID: 0000-0001-6818-0624

Шкуратенко О. В., кандидат юридичних наук, доцент завідувач кафедри історії держави та права Національної академії внутрішніх справ e-mai:kgpp@ukr.net ORCID: 0000-0002-1879-0085

\title{
ОРГАНІЗАЦІЙНО-ПРАВОВІ ЗАСАДИ ДІЯЛЬНОСТІ ДЕРЖАВНОЇ ЖАНДАРМЕРІЇ ЗАХІДНО-УКРАЇНСЬКОЇ НАРОДНОЇ РЕСПУБЛІКИ
}

У статті розглянуто історичні передумови утворення та діяльності Державної жандармерії ЗУНР. Детально проаналізовано організаційну діяльність та структуру цього правоохоронного органу. Висвітлено правові основи діяльності Державної жандармерії ЗУНР; ії̈ юридичний статус, функції, права та обов'язки. Окремо акцентовано увагу на особливому статусі Державної жандармерії з числа інших правоохоронних органів.

Ключові слова: Західно-Украӥнська народна республіка; Державна жандармерія; правоохоронні органи; правовий статус; правові акти.

В статье рассмотрено исторические предпосылки создания и деятельности Государственной жандармерии Западно-Украинской Народной Республики. Детально проанализировано организационную деятельность и структуру этого правоохранительного органа. Освещено правовые основы деятельности Государственной жандармерии ЗУНР; юридический статус, функции, права и обязательства. Отдельно акцентировано внимание на особый статус Государственной жандармерии с числа иных правоохранительных органов.

Ключевые слова: Западно-Украинская Народная Республика; Государственная жандармерия; правоохранительные органы; правовой статус; правовые акты.

Постановка проблеми. Після Україні розпочався процес реформуреволюції Гідності 2013-2014 рр. в вання правоохоронних органів, а 
відповідно удосконалення законодавства, яке б регламентувало їх діяльність. Формуючи основні напрямки правоохоронної політики органи державної влади України повинні враховувати не тільки досвід інших держав, але і свій історичний досвід, в тому числі й досвід становлення та діяльності органів охорони правопорядку Західноукраїнської народної республіки (далі ЗУНР). Адже розуміння історико-правових умов становлення та діяльності правоохоронних органів ЗУНР, знання особливостей їх правового статусу, може стати позитивним досвідом для практичної діяльності органів охорони правопорядку України в сучасних умовах.

За короткий час існування державності на землях Східної Галичини органи державної влади ЗУНР зуміли сформувати ефективно діючі органи охорони правопорядку, зокрема Державну жандармерію, яка забезпечила ефективний механізм протидії злочинності та забезпечення громадського порядку в тогочасних умовах. Цей історичний досвід практичного становлення правоохоронних органів зумовлює актуальність даної наукової статті.

Аналіз останніх досліджень та публікацій. Питаннями наукової розробки даної теми займалися радянські вчені О. Карпенко Б. Тищик, В. Кульчицький І. Васюта; українські науковці діаспори М. Лозинський, М. Чубатий, М. Стахів, В. Кучабський; українські історики незалежної України О. Вівчаренко, К. Науменко, С. Макарчук та інші. Безпосередньо питаннями становлення та розвитку правоохоронних органів ЗУНР займалися І. Сідак та К. Кравчук. Роботи I. Сідака присвячені розвідуваль- ним, в тому числі і правоохоронним органам, не тільки ЗУНР, але також i УНР, Гетьманської Держави та Директорії. В наукових роботах К. Кравчук дається тільки поверхневий аналіз даного питання.

Постановка завдання. Метою даної статті $\epsilon$ визначення місця Державної жандармерії ЗУНР в системі правоохоронних органів, встановлення їі організаційної структури, правового статусу, прав та обов'язків, правових засад діяльності, принципів взаємодії з іншими органами державної влади та населенням.

Виклад основного матеріалу. В умовах розпаду Австро-Угорщини та утвердження на землях Східної Галичини української державності в більшості повітів та міст українська влада приступила до ліквідації підрозділів австрійської жандармерії, яка виконувала функції загальної поліції. В замін цього органу влади повітові комісари та повітові ради приступили до формування нових органів охорони громадського порядку та боротьби із злочинністю. В різних місцевостях вони отримали різний статус, різні повноваження та відмінні назви. Вони називалися народною міліцією, поліцією, народною жандармерією, жандармерією та ін.

Так, 1 листопада 1918 року у Львові українські сили зуміли роззброїти австрійську міську поліцію, в склад якої входили: керівництво в особі директора поліції, трьох радників, сімох надкомісарів поліції, десяти комісарів поліції, п'ятнадцяти урядників, двох концептових урядників, 21 канцелярійного урядника 16 осіб допоміжного канцелярійного персоналу, корпусу поліцейських агентів в складі восьми районних 
інспекторів, 85 поліцейських агентів першого та другого класу, 8 сторожів поліційних арештів та п'яти їздових.

Крім цього, було інтерновано також військово-поліцейську сторожу міста в складі одного підполковника, 9 офіцерів нижчих чинів та 900 рядових. На місці цих установ було утворено українську поліцію Львова [1, с. 21].

В інших населених пунктах на народних зборах та вічах на добровільній основі утворювалася народна міліція. Такі підрозділи були сформовані в м. Сокаль в складі 200 чоловік [2, с. 31-33], в населених пунктах Бережанського, Долинського та інших повітів краю [3].

У деяких повітах повітові комісари та повітові національні ради зберегли жандармерію, кардинально оновивши її склад, поповнили її кадри патріотами української держави. Стосовно представників інших національностей - поляків, євреїв, німців, які проходили службу в австрійській жандармерії, то в тому випадку, коли вони присягнули на вірність Українській державі їм була надана можливість продовжити службу в українській державній жандармерії або отримати іншу роботу $[4$, с. 179$]$. В окремих повітах було збережено очищену від ворожих та ненадійних елементів жандармерію та паралельно сформовано підрозділи народної міліції чи поліції. Так, в Радехівському повіті було сформовано державну жандармерію в кількості 25 осіб та народну міліцію, в якій виявили бажання служити 860 чоловік [5, с. 20].

Однак, ці органи були місцевою самодіяльністю, не мали чітко визначеної структури, встановленого на державному рівні правового ста- тусу, їм бракувало висококваліфікованих, юридично грамотних фахівців які були б здатні до виконання обов'язків щодо охорони громадського порядку, боротьби з злочинністю та антидержавними проявами окремих, вороже налаштованих проти української державності осіб.

В умовах становлення державності, посилення протистояння 3 внутрішніми та зовнішніми ворогами, молодій українській державі потрібно було мати єдину систему організованих, дисциплінованих та професійно підготовлених органів охорони правопорядку, працівники яких були б відданими справі будівництва Української держави, готовими до самопожертви в ім'я ії інтересів. Тому вже 6 листопада 1918 року Українська Національна Рада за домовленістю з командуванням Української Галицької Армії розпоряджалася утворити «Корпус Української Державної жандармерії», першим головним командантом якої було призначено майора австрійської жандармерії П. Індишевського [6, c. 184].

На перших порах вона організаційно входила в структуру Державного секретаріату військових справ ЗУНР та підпорядковувалася Начальній військовій команді Української Галицької Армії та Державному секретарю військових справ Д. Вітовському.

Наступною, нижчою ланкою, були окружні команди жандармерії, кількість та назва яких відповідала кількості військових округів. В склад окружних команд входило дві-три повітові команди. Первинною ланкою організаційної структури Державної жандармерії ЗУНР були сільські та міські станиці. На перших початках 
існування особовий склад жандармських команд повинні були підбирати повітові комісари спільно 3 начальниками військових команд [7].

До Корпусу Української жандармерії можна було приймати і колишніх жандармів Австро-Угорщини українського походження, які зарекомендували себе з позитивної сторони за попереднього режиму.

Формування жандармерії проводилося на підставі розпорядження Державного Секретаріату ЗУНР, виходячи 3 положень австрійського закону про жандармерію від 25 грудня 1894 року, в тій частині, яка не суперечить інтересам української держав [8, с. 199]. 10 листопада 1918 року питання про Державну жандармерію розглядалося на засідання Державного Секретаріату (уряду) ЗУНР. 13 листопада 1918 року на виконання закону Української Національної Ради Державний Секретаріат прийняв розпорядження про створення державної жандармеpiï, яке було передане в усі повіти краю. В ньому повторно доводилося до відома місцевих адміністрацій про розпуск колишньої австрійської жандармерії та створення замість неї української жандармерії, 3 передачею останній всіх приміщень, матеріально-технічної бази та спорядження.

Проведення даної роботи було доручено окружним військовим командантам та повітовим комісарам. Державна жандармерія в листопаді 1918 року залишалася в подвійному підпорядкуванні: Державному секретаріату військових справ, який здійснював контроль за ії роботою через начальників окружних військових команд та Державному секретаріату внутрішніх справ, який ке- рував їі діяльністю через повітових комісарів [9].

Через деякий час, з метою усунення дублювання в керівництві роботою Державної жандармерії, було прийнято рішення про підпорядкування останньої відділу публічної безпеки Державного секретаріату внутрішніх справ [10, с. 39$]$.

Поряд 3 цим рядовий склад Державної жандармерії (жандармська мужва) та старшинський склад (офіцери) продовжували залишатися на військовій службі, керувалися в своїй діяльності військовими статутами, та з військових питань підпорядкувалися армійському командуванню. Чергові офіцерські звання жандармам також присвоювалися наказами Державного секретаря військових справ [11].

Створені підрозділи жандармерії в своїй діяльності повинні були керуватися старими австрійськими законами, а також постановами Української Національної Ради до прийняття органами влади ЗУНР нового законодавства, яке б визначало її правовий статус, як правоохоронного органу держави, регулювало основні напрямки її діяльності, визначало основні засади взаємозв'язків 3 іншими державними, в тому числі правоохоронними органами: повітовими комісарами, судами, прокуратурою, та ін.

Створені в перші революційні дні за народною ініціативою озбро$\epsilon$ ні загони народної міліції переходили в підпорядкування Державній жандармерії, як допоміжні воєнізовані формування. При необхідності в розпорядження Корпусу Української Державної жандармерії могли передаватися загони народного ополчення. 
Органи державної влади Західно-Української Народної Республіки бачили в Державній жандармерії правоохоронний орган, незалежний від втручання в його діяльність військових та цивільних відомств. Вони вимагали від командантів повітових жандармських команд суворого контролю за роботою підлеглих щодо недопущення 3 ïх боку порушень чинного законодавства, прав та законних інтересів громадян [12].

У зв'язку 3 введенням на території ЗУНР військовоадміністративного поділу на три військові області, Львівську, Тернопільську та Станіславську, в них було призначено керівників підрозділів жандармерії, так званих експонованих старшин, які безпосередньо підпорядковувалися начальній команді Державної жандармерії.

У листопаді 1918 року в цих областях було утворено 23 окружні відділи Державної жандармерії в наступних містах: Львів, Перемишль, Ярослав, Сянік, Самбір, Сокаль, РаваРуська, Городок, Дрогобич, Тернопіль, Теребовля, Бучач, Броди, Золочів, Бережани, Стрий, Долина, Чортків, Станіслав, Городенка, Коломия, Заставна, Чернівці.

Начальниками окружних відділів жандармерії призначалися як правило, старшини(офіцери), керівниками повітових команд - повітові вахмайстри, сільські та міські станиці очолювалися відповідно вахмайстрами першого та другого класу.

Після взяття армією Речі Посполитої Львова, Головна команда Державної жандармерії евакуювалася спочатку в м. Тернопіль, а потім у Станіславів, де перебувала до кінця травня 1919 року. Для контролю за поточною роботою Корпусу Україн- ської Державної жандармерії в Державному секретаріату внутрішніх справ було запроваджено посаду інспектора, на яку було призначено колишнього полковника жандармеpiї Австро-Угорщини О. Гаванського, який був досвідченим спеціалістом в цій галузі.

3 утвердженням державності на землях Східної Галичини удосконалювався ії правоохоронний апарат в особі Державної жандармерії, яка незважаючи на, як об'єктивні так і суб'єктивні труднощі, поповнювалася кваліфікованими кадрами, удосконалювала свою роботу. На службу в дану правоохоронну структуру поступали не тільки українці, але також і чехи, німці, євреї, які до розпаду Австро-Угорщини служили в Східній Галичині, чи постійно проживали там.

В Корпус Державної жандармеpiї активно вливалися й українці, жандарми та армійські офіцери колишньої Австро-Угорщини, яких події 1 листопада 1918 року застали в Західній Галичині, Боснії, Герцеговині, Хорватії, Чехії, Словаччині, Угорщині, які поверталися на Батьківщину щоб служити Україні.

Указані особи після перевірки та прийняття присяги на вірність Україні поступали на службу в Державну жандармерію. Відділи та станиці Корпусу також поповнювалися добровольцями 3 числа осіб, що пройшли військову службу в австрійській армії, мали відповідний освітній рівень, відповідали тим вимогам, що ставилися перед жандармами [13, c. 27].

Корінним чином було перебудовано організацію роботи жандармерії після 15 лютого 1919 року, коли Українською Національною Ра- 
дою було прийнято Закон «Про Державну жандармерію», який враховуючи основи державного устрою та організації влади та управління в ЗУНР регламентував її правовий статус, визначав права та обов'язки жандармів, підпорядкованість жандармерії, її територіальну організацію. У ньому встановлювався порядок прийому на службу та їі проходження, підстави звільнення зі служби, визначалися критерії професійного відбору жандармів - офіцерів та рядового складу, який в даному законі іменувався «жандармською мужвою». Закон складався 3 двох розділів (уступів) та сорока параграфів [14].

Слід також відмітити і те, що даний закон забезпечував належний правовий та соціальний захист правоохоронців. Основу даного нормативно-правового акту складали положення австрійського закону від 25 грудня 1894 року «Про жандармерію» $[8$, с. 201]. Поряд з цим у законі малися суттєві відмінності від австрійського аналогу викликані змінами в суспільно-політичній ситуації, які склалися в краї після 1918 року.

Доцільно також відмітити і те, що правовий статус цього важливого правоохоронного органу визначався не розпорядженнями та вказівками виконавчої гілки влади, а нормативно-правовим актом вищого органу законодавчої та представницької влади ЗУНР, що свідчить про ії значення та авторитет серед інших державних органів влади.

Аналізуючи закон Української Національної ради «Про Державну жандармерію» чітко видно, що цей нормативно-правовий акт регулює основні питання діяльності жандармерії та охоплює багато напрямків роботи, що розкриті в Законі України «Про Національну поліцію України». Дані нормативні акти мають багато спільного щодо проходження служби, прийому та звільнення з роботи. Однак, поряд з цим необхідно відмітити, що закон ЗУНР «Про Державну жандармерію» неоднозначно та недостатньо чітко визначав основні права та обов'язки жандармів щодо участі в охороні громадського порядку та боротьбі із злочинністю. В ньому нічого не говориться про права жандармів щодо затримання злочинців та порушників, проведення дізнання та попереднього слідства.

Державна жандармерія ЗУНР являла собою воєнізований , озброєний орган виконавчої влади, який мав завданням захищати суспільний лад, підтримувати спокій та порядок в країні. Поряд 3 цим являючись військовим формуванням, вона могла залучатися до участі в бойових діях, виконання окремих завдань на фронті чи в прифронтовій смузі, якщо в цьому була необхідність, та якщо це не шкодило виконанню покладених на неї обов'язків щодо захисту державного ладу.

Як і до 15 лютого 1919 року, Державна жандармерія залишилася в підпорядкуванні Державного секретаріату внутрішніх справ та організаційно входила в його четвертий відділ “жандармерії та поліції". На співробітників корпусу поширювалися військові закони та дисциплінарні статути. Четвертий відділ Державного секретаріату внутрішніх справ очолив майор Волощук [8, c. 205]. Безпосередньо Начальну команду Української Державної Жандармерії очолив підполковник О. Красіцький, його заступником став майор П. Індишевський.[15, с. 207] 
У червні 1919 року, після встановлення Виділом УНР диктатури та оголошення $€$. Петрушевича повновладним диктатором ЗУНР, Корпус Державної жандармерії знову передають в відання військового командування УГА. Він підпорядковується «Команді запілля Начальної Команди Української Галицької Армії», а пізніше перепідпорядковується безпосередньо військовій канцелярії Диктатора. В цей період жандармерію очолює майор І. Дичко.

Тоді ж і було прийнято рішення про перейменування Державної жандармерії на «Народну сторожу» [16, c. 305]. Зміна назви цього правоохоронного органу була викликана політичними обставинами. Українська Галицька Армія, всі урядові установи ЗУНР у червні 1919 року внаслідок невдач на українсько-польському фронті змушені були тимчасово покинути територію Східної Галичини та евакуюватися на Східну Україну. Назва “жандармерія" асоціювалося в населення Великої України з спогадами про царську жандармерію та викликала в нього негативні емоції.

Народна сторожа виконувала ті ж функції, що і Державна жандармерія: охороняла суспільний лад та безпеку, розшукувала злочинців, боролася 3 шпигунством та дезертирством, займалася питаннями мобілізації в армію та охорони військового майна, продовольчого забезпечення збройних сил, припиняла протиправні дії щодо населення.

В прифронтовій смузі особовий склад Народної сторожі виконував також військово-поліцейські функції, а при необхідності з зброєю в руках займав позиції в окопах чи ставав в ряди наступаючих вояків Української Галицької Армії.
Народна сторожа активно співпрацювала з народною міліцією УНР, державною інституцією, встановленою для охорони державного ладу, публічного спокою та порядку, попередження, виявлення та розслідування карних вчинків [17].

Народна сторожа надавала практичну та правову допомогу державним адміністраціям та повітовим комісарам в організація роботи, так як значна частина цивільних чиновників не мала правової підготовки. В діяльності цього правоохоронного органу мали місце випадки, коли військові чини та повітові комісари давали йому вказівки та розпорядження, які виходили за межі їх повноважень, що викликало невдоволення населення та певну недовіру певної частини населення до Народної сторожі [8, с. 203].

В кінці липня 1919 року, після невдачі Чортківського наступу на позиції поляків, Українська Галицька Армія, а разом із нею і Народна сторожа, остаточно перейшли на Східну Україну та влилися в Дієву армію УНР. Частини третього корпусу УГА разом із жандармськими підрозділами Самбірського, Дрогобицького та прилеглих повітів були витіснені ворогом на територію Чехословаччини, а окремі були інтерновані польськими та румунськими військами [18, с. 246].

у Кам'янець-Подільський, тодішню столицю Української Народної Республіки, разом з УГА та урядовими установами прибула і Народна сторожа в складі 25 офіцерів, 900 заводових, 2500 пробних жан дармів і 2000 народних міліціонерів.

У зв'язку з втратою державності, військовою поразкою Української 
Галицької Армії в війні за незалежність з Польщею та Румунією, по різному склалася доля частин та особового складу Корпусу Української Державної жандармерії (Народної сторожі).

Після переходу УГА на сторону більшовиків та утворення Червоної Української Галицької Армії польовий штаб Робітничо-Селянської Червоної Армії розпустив Народну сторожу, а рядових жандармів та старшин направив для проходження служби в бригади. В окремих військових підрозділах вони залучалися до військово-поліцейської служби. Окремі жандарми поступили на службу в Дієву армію або органи безпеки УНР.

Ti співробітники жандармерії, які волею долі були інтерновані в Чехословаччині разом з частинами третього корпусу УГА поступали на службу в формування військової поліції, яка несла службу в містах та таборах військовополонених та надавала практичну допомогу станицям жандармерії Чехословаччини [13, с. 23-24].

Підрозділи жандармерії на місцях: в селах, містах, повітах та округах знаходилися в подвійному підпорядкуванні - органам місцевої влади в особі повітових та міських комісарів та вищестоящому командуванню - окружним командам жандармерії та іï Начальній команді.

Повітові комісари мали право маневрувати силами жандармерії, виходячи соціально-економічної та політичної ситуації в регіоні та стану оперативної обстановки. Що стосується професійної підготовки, військових справ, проходження служби, адміністративно-господарської та службової діяльності, то 3 цих пи- тань вони підпорядковувалися по вертикалі - вищим командам.

Жандармерія зобов'язана була надавати в межах своєї компетенції необхідну допомогу військовим та цивільним установам, однак останні були позбавлені можливості впливати на прийняття посадовими особами жандармерії рішень. Вони зобов'язані були керуватися у своїй діяльності тільки чинним законом. В обов'язки цього правоохоронного органу входило також надання необхідної правової допомоги органам прокуратури та судочинства.

В свою чергу Державна жандармерія була наділена правом вимагати у цивільної та військової влади необхідної допомоги 3 питань, що стосуються забезпечення виконання покладених на неї обов'язків щодо охорони суспільного порядку та боротьби із злочинністю.

При виконанні покладених на неї обов'язків жандармерія повинна була неухильно дотримуватися чинного законодавства ЗУНР та чинних австрійських законів. Однак, як військова організація, вона зобов'язана була та безумовно виконувала всі вказівки, накази та припоручення, не вдаючись в їх правову оцінку на предмет відповідності чинному законодавству. За законність вказівки та розпорядження особисто відповідав той службовець, який його видав. 3 цією метою в організації роботи підрозділів жандармерії практикувалося видавати всі накази та розпорядження в письмовій формі, наскільки це було можливо в умовах ведення бойових дій чи при конкретній оперативній обстановці або ситуації [8, c. 200].

Співробітники жандармерії являлися державними службовцями, 
виступали від імені української держави та були наділені відповідними правами, маючи певне коло обов'язків перед державою та народом.

Виконуючи службові обов'язки, та даючи розпорядження жандарм зобов'язаний був вжити словосполучення «В іменизакона». В цих випадках всі особи, в тому числі і військовослужбовці, що були під юрисдикцією військового судівництва, зобов'язані були виконати всі розпорядження жандарма, маючи при цьому право оскаржити його дії [19].

Співробітники Державної жандармерії при виконанні службових обов'язків були наділені правом застосування табельної вогнепальної зброї в наступних випадках:

При «конечній» обороні при потребі відбиття нападу на працівника жандармерії та інших осіб, якщо це загрожувало їхньому життю і якщо іншим способом відбити напад було неможливо;

Коли особа, відносно якої здійснюється затримання, чинить опір;

При намаганні небезпечного злочинця втекти, якщо немає іншого способу для його затримання [8, c. 200].

Крім цього жандарми були наділені рядом інших прав щодо забезпечення ефективного виконання покладених на них обов'язків в охороні суспільного порядку, боротьбі із злочинністю, попередженні та припиненні антидержавної діяльності, фактів шпіонажу, саботажу, диверсій та ін.

Вони були наділені правом використовувати в службовій діяльності послуги таємних інформаторів, здійснювати за особами, що представляють оперативний інтерес візуальне спостереження, проводити опи- тування правопорушників, злочинців, свідків та потерпілих, проводити огляди та обшуки жилих та службових приміщень та фізичних осіб, займатися вивідуванням (мається на увазі особистий пошук та розвідувальне опитування) здійснювати контроль за телефонними розмовами та поштово-телеграфною кореспонденцією [8, с. 203-204].

Державна жандармерія, будучи органом державної влади, 3 метою профілактики протиправних діянь була наділена правом викликати громадян для співбесіди.

Як ми бачимо, вона виконувала функції органу дізнання 3 правом займатися оперативно-розшуковою діяльністю. Проведення попереднього слідства по кримінальних справ знаходилося в компетенції цивільних та військових судів.

Слід також відмітити, що основні положення закону від 15 лютого 1919 року «Про Державну жандармерію» в повному об'ємі не охоплювали всі аспекти службової діяльності цього органу державної влади.

По-перше, не було чіткої регламентації функцій та основних напрямків службової діяльності Державної жандармерії.

По-друге, закон практично визначав повноваження жандармерії щодо затримання та арешту громадян, процесуальні права її співробітників.

По-третє, в законі відсутня внутрішня структура державної жандармерії, не визначалися галузеві відділи та напрямки їх роботи, не встановлювалися принципи організації взаємодії з іншими органами державної влади ЗУНР.

По-четверте, він не визначав переліку конкретних кримінальних 
та адміністративних справ, які відносяться до компетенції Державної жандармерії.

Висновки. Таким чином правові умови формування правоохоронних органів ЗУНР були викликані розпадом Австро-Угорської монархії, що стався внаслідок поразки в Першій світовій війні та жовтневої 1918 року революції.

В основному на початковому етапі всі правоохоронні структури ЗУНР керувалися в своїй службовій діяльності старим законодавством Австро-Угорської імперії, якщо воно не знаходилося в протиріччі з інтересами української держави. В подальшому державні органи ЗУНР за короткий час зуміли створити дієву систему правоохоронних органів, які зуміли належним чином організувати роботу, забезпечували належний правопорядок в державі, виконували покладені на них функції підтриман- ня боєздатності армії, забезпечення нормальної роботи транспорту та ін. Правовий статус, права та обов'язки правоохоронних органів були чітко врегульовані нормативно-правовими актами. Більшість 3 них мали вищу юридичну силу, тобто були прийняті Українською Національною Радою.

У свою чергу Державна жандармерія Західно-Української Народної Республіки була повноцінним правоохоронним органом, який діяв на підставі чинного законодавства прийнятого вищими органом державної влади, мав визначені на державному рівні права та обов'язки щодо охорони громадського порядку, попередження та припинення злочинів та правопорушень, боротьби з шпіонажем, саботажем, дезертирством та іншими антидержавними проявами та користувався заслуженим авторитетом у населення Західної України.

\section{Список використаних джерел}

1. Єліяшевський О. Дирекція поліції у Львові в часи листопадового зриву. У книзі Українська Галицька Армія. До 40-річчя ㅃ̈̈ участі у визвольних змаганнях в 19181920 р.p. Матеріали до історії. Т. II. Вінніпег, 1960. 316 с.

2. Микитюк Д. Запільні органи правопорядку 30 УНР. У книзі Українська Галицька Армія. До 40-річчя її участі у визвольних змаганнях в 1918-1920 рр. Матеріали до історії. Т. II. Вінніпег, 1960. 316 с.

3. Кравчук К. Правоохоронні органи Західноукраїнської Народної Республіки. Науковий збірник ЮІ ТАНГ. Випуск 1. Тернопіль, 2000. С. 45-46.

4. Кульчицький В., Настюк М., Тищик Б. Історія держави і права України. Львів : Світ, 1996. 296 с.

5. Костицький М. Р., Тищик Б. Й. Західно-Українська Народна Республіка (1918-1923). Львів : Світ, 1992. 98 с.

6. Західно-Українська Народна Республіка 1918-1923. Історія / Під ред. К. Карпенко. Івано-Франківськ, 2001. 454 с.

7. Державний архів Львівської області. Фонд 257, опис 1, справа 72, аркуш 63.

8. Сідак I. Національні спецслужби в період Української революції 19171921 рр Львів, 1993. 297 с.

9. Центральний державний історичний архів у Львові. Фонд 581, оп. 1, Справа 96, аркуш 1-6.

10. Тищик Б. Й., Вівчаренко О. А. Західноукраїнська Народна Республіка. 19181923. (До 75-річчя утворення і діяльності). Коломия, 1993. 310 с. 
11. Вісник Державного секретаріату військових справ. Ч. 5. Станіславів 31 січня 1919. С. 2-3.

12. Центральний Державний історичний архів вищих органів влади та управління. Фонд 1092, опис 3, справа 107, аркуш 1-6.

13. Козак I. Дещо про Державну жандармерію ЗУНР. Украӥнський скиталець, 1923. Ч. 16 (38). 275 с.

14. Центральний Державний історичний архів вищих органів влади та управління. Фонд 581, опис 1, справа 163, аркуш 13-16.

15. Рубльов О.С., Реєнт О.П. Українські визвольні змагання 1919-1921 pp. Т.10. Київ, 1999. 518 с.

16. Шаньковський Л. Українська Галицька Армія. Воєнно-історична студія. Львів : Світ, 1999. 454 с.

17. Центральний Державний історичний архів вищих органів влади та управління. Фонд 1092, опис 1, справа 3, аркуш 1-9.

18. Історія Українського війська. Крип'якевич І., Гнатевич Б., Стефанів 3. Т. ІІ. Київ, 1995. 476 с.

19. Центральний державний історичний архів у Львові. Фонд 581, оп. 1, Справа 163 , аркуш 1-14.

\section{References}

Yeliyashevskij, O. (1960). Direkciya policiyi u Lvovi v chasi listopadovogo zrivu. Ukrayinska Galicka Armiya. Do 40-richchya yiyi uchasti u vizvolnih zmagannyah v 19181920 rr. Materiali do istoriyi. T. II. Vinnipeg [in Ukrainian].

Mikityuk, D. (1960). Zapilni organi pravoporyadku ZO UNR. U knizi Ukrayinska Galicka Armiya. Do 40-richchya yiyi uchasti u vizvolnih zmagannyah v 1918-1920 rr. Materiali do istoriyi. T. II. Vinnipeg [in Ukrainian].

Kravchuk, K. (2000). Pravoohoronni organi Zahidnoukrayinskoyi Narodnoyi Respubliki. Naukovij zbirnik YuI TANG. Vipusk 1. Ternopil, 45-46 [in Ukrainian].

Kulchickij, V., Nastyuk, M., Tishik, B. (1996). Istoriya derzhavi i prava Ukrayini. Lviv: Svit [in Ukrainian].

Kostickij, M. R., Tishik, B. J. (1992). Zahidno-Ukrayinska Narodna Respublika (19181923). Lviv: Svit [in Ukrainian].

Karpenko, K. (Red.). (2001). Zahidno-Ukrayinska Narodna Respublika 1918-1923. Istoriya. Ivano-Frankivsk [in Ukrainian].

Sidak, I. (1993). Nacionalni specsluzhbi v period Ukrayinskoyi revolyuciyi 1917-1921 r.r. Lviv [in Ukrainian].

Tishik, B. J., Vivcharenko, O. A. (1993). Zahidnoukrayinska Narodna Respublika. 19181923. (Do 75-richchya utvorennya i diyalnosti). Kolomiya [in Ukrainian].

Kozak, I. (1923). Desho pro Derzhavnu zhandarmeriyu ZUNR. Ukrayinskij skitalec, 16 (38) [in Ukrainian].

Rublov O. S., Reyent O. P. (1999). Ukrayinski vizvolni zmagannya 1919-1921 rr. T.10. Kiyiv [in Ukrainian].

Shankovskij, L. (1999). Ukrayinska Galicka Armiya. Voyenno-istorichna studiya. Lviv: Svit [in Ukrainian].

Istoriya Ukrayinskogo vijska. (1995). Krip'yakevich I., Gnatevich B., Stefaniv Z. T. II. Kiyiv [in Ukrainian]. 
V. Prus, PhD, Associate Professor, Docent of the Departmen of History of State and Law, National Academy of Internal Affairs e-mai:pvz_@ukr.net; ORCID:0000-0001-6818-0624

o. Shkuratenko, PhD, Associate Professor, Head of the Departmen of History of State and Law, National Academy of Internal Affairs

e-mail: kgpp@ukr.net; ORCID: 0000-0002-1879-0085

\section{Organizational and legal grounds of activity of state gendarmerie in West Ukrainian People's Republic}

In the article are considered historical prerequisites of establishment and activity of State gendarmerie of WUPR. There is analyzed in detail the structure and the organizational activity of this law enforcement body. The legal grounds of State gendarmerie's activities are highlighted as well as its legal status, functions, rights and obligations. Separately focused an attention to the special status of the State gendarmerie among other law enforcement bodies, on which structure in a short period of time were established an effective system of divisions. These divisions were able to organize work properly, to ensure the legal order in state, to act accordingly to their national security functions, to maintain stable transports work. The legal status, rights and obligations of State gendarmerie were strictly regulated by legal acts. Most of them had the highest law power, meaning they were passed by Ukrainian National Counsel and therefore were laws.

Along with that, the effectiveness of the State gendarmerie was provided by the patriotism and heroism of the employees, who besides their main professional obligations were soldiers of WUPR, armed they protected the sovereignty, territorial integrity and inviolability of WUPR.

Courage, heroism, devotion, love to Ukraine and readiness for self-sacrifice for its interests, showed by the workers of gendarmerie in such an unstable years have to be an example for the employees of National police of Ukraine. We all have to remember, what have they sacrificed for the development of sovereign Ukraine is the most valuable thing - their lives, with the belief that our homeland will become equal between equal world's states, and that Ukrainian nation will gain a wanted independency.

Keywords: West Ukrainian People's Republic; State gendarmerie; law enforcement bodies: legal status; legal acts. 